Available online at: http://proceeding.rsfpress.com/index.php/ic-smart/index

Proceeding on International Conference of Science Management Art Research Technology

(IC-SMART)

Volume 1 Number 1 (2020): 1-10

\title{
Analysis of the Effect of School Governance and Total Quality Management on the Effectiveness of Vocational School-based Entreprise
}

\author{
Arie Wibowo Khuriniawan, Illah Sailah, Pudji Muliono, M Syamsul Maarif, \\ Bambang Indriyanto \\ Bogor Agricultural University, Bogor, Indonesia \\ E-mail address ariedmb13@gmail.com
}

\begin{abstract}
Recently, the Indonesian government is focusing on improving the quality and effectiveness of Vocational High Schools (SMK) as mandated in Presidential Instruction No. 9 of 2016 concerning SMK Revitalization. One manifestation of efforts to improve the quality of education is by transforming SMK into a vocational school-based enterprise. This study aims to analyze the factors influencing the effectiveness of Vocational school-based enterprise management through the implementation of School Governance (SG) and Total Quality Management (TQM). This study used a quantitative approach using descriptive statistics and PLS-SEM analysis. The data was obtained by distributing questionnaires to students, teachers, principals, and committees in 25 vocational school-based enterprises in East Java and DKI Jakarta. The results show that the modeling was valid, consistent, and good modeling. In addition, it is found that SG and TQM had a positive and significant effect on improving the effectiveness of the management of vocational schools with R2 by $92.2 \%$.
\end{abstract}

Keywords: effectiveness of school, school governance, SEM PLS, Vocational school-based enterprise, TQM

\section{INTRODUCTION}

This is an open access article under the CC-BY-NC license.

Nowadays, the condition of the workforce in Indonesia is dominated by the majority of the workforce, with low levels of education of 58.77 percent or 72.8 million population (BPS, 2020). On the other hand, Indonesia is entering an era of demographic bonuses marked by a decrease in the ratio between nonproductive populations to the number of productive population aged 15-64 years (Kemenpppa, 2018). Demographic bonuses in Indonesia dominated with an average high school education level greatly affect the level of national productivity. This is proven by the level of productivity of Indonesian labor, which is relatively lower compared to other neighboring countries. The productivity level of Indonesia is only $1.37 \%$, or almost four times lower than Thailand's productivity, which reached $5.28 \%$. Indonesia's production value is also lower when compared to Vietnam $(4.39 \%)$ and Malaysia (2.16\%) (APO, 2018). 
Proceeding on International Conference of Science Management Art Research Technology (IC-SMART),

Vol. 1 (1), 1-10

Analysis of the Effect of School Governance and Total Quality Management on the Effectiveness of Vocational School-based Entreprise

Arie Wibowo Khuriniawan, Illah Sailah, Pudji Muliono, M Syamsul Maarif, Bambang Indriyanto

This condition encourages the Indonesian government to immediately prepare a qualified and skilled workforce to increase productivity and competitiveness through education. One of the government's strategies to prepare a quality and skilled workforce is through increasing access, quality, and relevance of education, including developing Vocational High School. This is mainly because the current vocational education tends to produce a large number of semi-skilled graduates, while the job market has limited capacity to absorb these graduates.

At present, the Indonesian government is focusing on improving the quality and effectiveness of SMK by transforming into a vocational school-based enterprise called SMK-BLUD. This school is given flexibility in financial management to provide services to the community in order and to improve vocational student competencies and cooperation with industry based on the principles of efficiency and productivity. This means that SMK is not only seen as an educational institution but also as a corporation requiring overall management, which includes planning, organizing, implementing, monitoring, teaching, finance, wealth, human resources, strategy, marketing, and development. Vocational school-based enterprise is believed to be able to participate in improving services to the community in order to advance public welfare and educate the nation's life.

The effectiveness of a school is demonstrated by the ability of schools to carry out their functions as the best place to learn by providing quality services for their students (Scheerens, 2013). The achievement of educational outcomes does not only emphasizes the cognitive aspects but balancing with comprehensive learning outcomes for all parties. On the other hand, according to Sadikoglu \& Olcay (2014), one of the steps that schools can take to improve the quality of education is by applying TQM. TQM is a way of managing management to improve the effectiveness, flexibility, and competitiveness of the organization as a whole (Dotchin \& Oakland, 2006). This study aims to analyze the effect of the application of SG and TQM on the effectiveness of Vocational school-based enterprise management. It is hoped that through this research, an effective strategy will be obtained to increase the effectiveness of the management of Vocational school-based enterprise based on SG and TQM (Nugroho, 2014).

\section{LITERATURE REVIEW}

\section{II.1 School Governance}

School Governance contains a basic definition of a school having the right to autonomy in carrying out its school management, especially in the management of human, financial and material resources in schools (Grauwe, 2005). SG becomes a school management model giving schools considerable autonomy, especially school principals, to make decisions on significant issues related to school management within a framework that includes decisions about curriculum and learning management; recruitment and management of education personnel; and school financial management (Arar \& Abu-Romi, 2016; Caldwell, 2005). Five principles were adopted to apply good SG, namely: transparency, accountability, responsibility, independence, and equality (Quyen, 2014) and three other principles, namely participation, predictability, and dynamic.

\section{II.2 Total Quality Management (TQM)}

TQM is defined as a general management philosophy and a set of tools that enable institutional improvement to be ensured by customer satisfaction with the services they have received (Cardoso, Rosa, Maria, Videira, \& Amaral, 2018). In the context of education, TQM is related to continuous improvement that can provide a set of practical tools to every educational institution in meeting the needs, desires, and expectations of customers, now and in the future (Sallis, 2010). In this study, TQM core values are based on a focus on customers, the participation of all parties, focus on the 
Proceeding on International Conference of Science Management Art Research Technology (IC-SMART),

Vol. 1 (1), 1-10

Analysis of the Effect of School Governance and Total Quality Management on the Effectiveness of Vocational School-based Entreprise

Arie Wibowo Khuriniawan, Illah Sailah, Pudji Muliono, M Syamsul Maarif, Bambang Indriyanto

process, continuous improvement, and fact-based decisions as outlined by Bergman \& Klefsjö (1994) and Kanji, Malek, \& Tambi (1999).

\section{II.3 Effectiveness of school}

The effectiveness of school management in educational institutions implies that the school is able to carry out its function as the best place of learning by providing quality services for students who are targeted in a certain period of time (Scheerens, 2000). The effectiveness of school management builds achievement not only on students but on all components, which are its scope. The principle of effectiveness of school management in this study refers to Hoy, Jardine, \& Wood (2005) and Scheerens (2000), namely strong leadership, emphasis on acquiring basic skills (curriculum), school climate, high expectations of student achievement, and continuous evaluation. To add to the novelty in this study, finansial management flexibility was included as a principle of effective school management.

\section{II.4 Relationship between TQM and SG}

The relationship between TQM and SG revealed that in terms of improving the quality of schools, the role of the principal in implementing SG was very important in staff development, physical development, and student development (Liantos \& Pamatmat, 2016). This shows that student development is highly dependent on the performance of leaders in particular, and the school system in general. TQM practices relating to leadership, focus on clients, commitment to change and continuous improvement, data-based decision making, professional learning, and system focus are found to have a relationship with school leadership and improvement in terms of staff development ((Liantos \& Pamatmat, 2016).

\section{II.5 Relationship between SG and School Management Effectiveness}

Caldwell (2005) states that schools that use all SG components will significantly improve the learning and teaching process. This research is also supported by research by Volansky \& Friedman (2003), stating that the decentralization of reforms provides significant improvements, both improving education and learning achievement and increasing school effectiveness. SG can also help schools to improve the quality of education, provide a healthier learning and teaching environment while increasing student achievement (Gamage \& Zajda, 2009; Sabas \& Mokaya, 2015).

\section{II.6 Relationship between TQM and School Management Effectiveness}

Hoyle (1986) states that TQM is related to guiding practices and enables practitioners to increase organizational effectiveness. Meanwhile, Oakland (2000) and Summers (2006) revealed that TQM is a way of managing to improve the effectiveness, flexibility, and competitiveness of the organization as a whole. This indicates a relationship between management and performance. According to Lezotte (1992), there is a significant relationship between the principles of total quality management and the principles of effective schooling. Total quality management practices in schools provide a perspective to see the problems faced by schools and as a tool to remove barriers to effective schooling.

\section{RESEARCH METHODOLOGY}

This research used a quantitative approach with descriptive statistics and PLS-SEM analysis. The data was collected by distributing questionnaires to 231 respondents consisting of students, teachers, principals, and committees in 25 vocational school-based enterprises in the provinces of East Java and DKI Jakarta. Samples were selected using a proportional stratified random sampling technique. 


\section{FINDING AND DISCUSSION}

\section{IV.1. Descriptive Statistics Analysis}

Respondent characteristics based on demographics include occupational characteristics, gender, age, the province, as shown in Table 1. Most respondents in the study came from the teacher that are 127 people (55\%). Respondents who have status as students came in second place that are 82 students $(35.5 \%)$. Meanwhile, respondents from the principal were 16 people $(6.9 \%)$, and the committee were six people (2.6\%). This study involved respondents with almost equal proportions of male and female sexes. Respondents in this study were dominated by age $\leq 20$ years who came from a group of students as many as $35.5 \%$ and dominated by respondents from East Java that are 182 respondents or $78.8 \%$.

Table 1. Demographic characteristics of respondents

\begin{tabular}{llll}
\hline Category & Characteristics & Number (n) & Percentage \\
\hline Profession & Student & 82 & $35.5 \%$ \\
& Teacher & 127 & $55.0 \%$ \\
& Headmaster & 16 & $6.9 \%$ \\
& Committee & 6 & $2.6 \%$ \\
\hline Gender & Man & 116 & $50.2 \%$ \\
& Women & 115 & $49.8 \%$ \\
\hline Age & $\leq 20$ years old & 82 & $35.5 \%$ \\
& 21-30 years old & 3 & $0.9 \%$ \\
& 31-40 years old & 21 & $9.1 \%$ \\
& 41-50 years old & 62 & $26.8 \%$ \\
& $>50$ years old & 64 & $27.7 \%$ \\
\hline Province & East Java & 182 & $78.8 \%$ \\
& DKI Jakarta & 49 & $21.2 \%$ \\
\hline
\end{tabular}

\section{IV.2. SEM PLS Analysis}

This study used the SEM-PLS approach to measure the effect of SG and total TQM on school effectiveness in the vocational school-based enterprise.

\section{Measurement Model}

Measurement model testing is used to confirm whether the indicators used in the model can define a construct. In evaluating the measurement model, tests are performed on a) convergent validity, $b$ ) discriminant validity, and c) composite reliability.

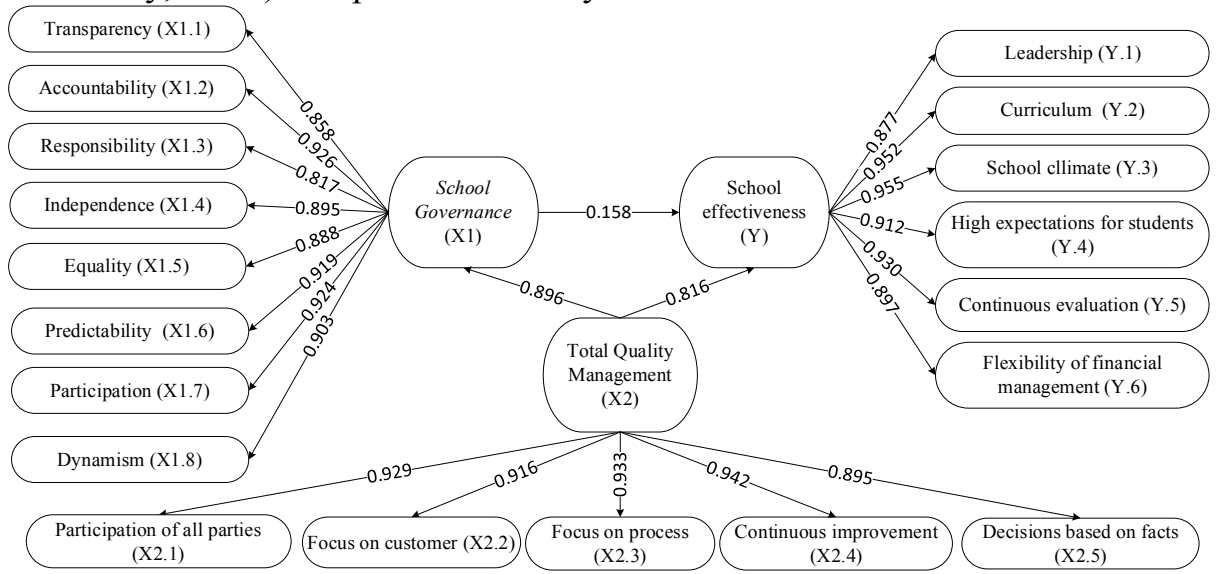

Figure 1. Measurement Model 
Proceeding on International Conference of Science Management Art Research Technology (IC-SMART),

Vol. 1 (1), 1-10

Analysis of the Effect of School Governance and Total Quality Management on the Effectiveness of Vocational School-based Entreprise

Arie Wibowo Khuriniawan, Illah Sailah, Pudji Muliono, M Syamsul Maarif, Bambang Indriyanto

\section{Convergent Validity}

Convergent validity is used to measure the correlation between variables in the model with its indicators. If the loading factor value $\geq 0.5$, the convergent validity is fulfilled, indicating that the constructs of the latent variable indicator are valid. Based on Table 2, it is found that the loading factor values range from 0.817 to 0.955 . This value is much greater than 0.5 . This indicates that the convergent validity that compiles each indicator of the school effectiveness variable is fulfilled or all statements that compile the indicators on the SG, TQM, and school effectiveness variables are valid.

\section{Discriminant Validity}

Discriminant validity is an analysis to determine whether indicators can reflect latent variables. The discriminant validity value of the model is measured by the cross-loading value for each indicator on the latent variable. If the correlation value between latent variables to the indicator is greater than the value of the correlation of other variables, it means that the variable is better in predicting indicators than other variables. Based on the result, all cross-loading values between the indicator and the construct are greater than the value of the cross-loading indicator with the other constructs. It means that the value of cross-loadings between the indicator and its construct has met the discriminant validity.

On the other hand, the Average Variance Extracted (AVE) value of each latent variable can be used to determine the valid indicator. AVE values indicate the average variance obtained by each latent variable from each indicator. In general, if the AVE value is $\geq 0.5$, then the discriminant validity is achieved. AVE values for all indicators and latent variables have met the minimum limit $(0.5)$, which is around 0.619 to 0.882 . This indicates that indicators and latent variables already have good discriminant validity, where latent variables can explain an average of more than half the variance of the indicators.

\section{Composite reliability.}

If the value of composite reliability exceeds 0.7 or if the Cronbach's Alpha value for each latent variable is greater than 0.60 , it indicates that the indicators have consistency in measuring their respective latent variables. Based on Table 2, the results are obtained that the Cronbach's Alpha value of all the indicators is in the range of 0.741 to 0.977 , meaning the value has exceeded the minimum standard (0.6). Meanwhile, the composite reliability value of all the indicators is more than 0.7 , which is in the range of 0.879 to 0.974 . Therefore, it can be stated that all indicators are reliable and consistently measured each indicators.

Table 2 Loading factor

\begin{tabular}{clll}
\hline Variable $\quad$ Indicator & AVE & $\begin{array}{l}\text { Cronbach's } \\
\text { Alpha }\end{array}$ & $\begin{array}{l}\text { Composite } \\
\text { Reliability }\end{array}$ \\
\hline School governance (X1) & & & \\
Transparency (X1.1) & 0.713 & 0.798 & 0.882 \\
Accountability (X1.2) & 0.767 & 0.848 & 0.908 \\
Responsibility (X1.3) & 0.794 & 0.741 & 0.885 \\
Independence (X1.4) & 0.708 & 0.794 & 0.879 \\
Equality (X1.5) & 0.836 & 0.804 & 0.911 \\
Predictability (X1.6) & 0.796 & 0.872 & 0.921 \\
Participation (X1.7) & 0.744 & 0.885 & 0.921 \\
Dynamism (X1.8) & 0.841 & 0.905 & 0.941
\end{tabular}

Total quality management (X2) 
Proceeding on International Conference of Science Management Art Research Technology (IC-SMART), Vol. 1 (1), 1-10

Analysis of the Effect of School Governance and Total Quality Management on the Effectiveness of Vocational School-based Entreprise

Arie Wibowo Khuriniawan, Illah Sailah, Pudji Muliono, M Syamsul Maarif, Bambang Indriyanto

\begin{tabular}{llll}
\hline Participation of all parties (X2.1) & 0.753 & 0.836 & 0.902 \\
Focus on customer (X2.2) & 0.774 & 0.854 & 0.911 \\
Focus on the process (X2.3) & 0.717 & 0.868 & 0.910 \\
Continuous improvement (X2.4) & 0.760 & 0.895 & 0.927 \\
Decisions based on facts (X2.5) & 0.844 & 0.815 & 0.915 \\
School Effectiveness (Y) & & \\
Leadership (Y.1) & 0.882 & 0.866 & 0.937 \\
Curriculum (Y.2) & 0.758 & 0.936 & 0.949 \\
School climate (Y.3) & 0.762 & 0.922 & 0.941 \\
High expectations for students (Y.4) & 0.798 & 0.873 & 0.922 \\
Continuous evaluation (Y.5) & 0.652 & 0.893 & 0.918 \\
Flexibility of financial management (Y.6) & 0.743 & 0.827 & 0.897 \\
\hline
\end{tabular}

\section{IV.3. Structural Models}

The relationship between exogenous variables and endogenous latent variables in a model is explained in the structural model. Evaluation of structural models in SEM-PLS was carried out with three criteria, namely the $\mathrm{R}^{2}, \mathrm{Q}^{2}$, and GoF.

The determination coefficient $\left(R^{2}\right)$

The $\mathrm{R}^{2}$ test is carried out to find out how large the percentage of the variance of each endogenous latent variable is explained by the exogenous latent variable. The value of $\mathrm{R}^{2}$ owned by the school governance variable is 0.802 , meaning that $80.2 \%$ of the variance of latent variables in school governance can be explained by the total quality management variable. Meanwhile, the $\mathrm{R}^{2}$ value for the school effectiveness variable is 0.922 , meaning that $92.2 \%$ of the variance of school effectiveness can be explained by the school governance and total quality management variable. Moreover, $7.8 \%$ of the variance of school effectiveness is influenced by other latent variables that is not explained in this research model. The two endogenous latent variables have high $\mathrm{R}^{2}$ values meaning that the structural models are good.

\section{Predictive Relevance $\left(Q^{2}\right)$}

Evaluation of $\mathrm{Q}^{2}$ is used to validate the model calculated from the total value of $\mathrm{R}^{2} . \mathrm{Q}^{2}$ value $=0.9845$, meaning that $98.45 \%$ of the variance of endogenous latent variables is explained by the exogenous latent variables proposed in the model. The rest is explained by other exogenous variables that are not contained in the model.

\section{Goodness Of Fit (GoF)}

GoF is used to measure the overall quality of the model, both the measurement and structural model. GoF values are obtained from the average commonality and the average $\mathrm{R}^{2}$ value of each latent variable. A GoF value closes to one (1) states that the model is getting better. The results show that the GoF value of 0.6487 , meaning that the goodness of the structural and measurement model is $64.87 \%$. This value is categorized as a large GoF because it tends to approach 1, indicating that the model formed is very good and fulfills a high ability in explaining empirical data.

\section{IV.4. Hypothesis Testing}

To determine the effect of exogenous variables on endogenous latent variables, a significance test was performed. Testing the hypothesis in this study using the results of t-statistics and the value of probability (p). If the t-statistics test value is greater than the Table-t value or the - value is smaller 
Proceeding on International Conference of Science Management Art Research Technology (IC-SMART),

Vol. 1 (1), 1-10

Analysis of the Effect of School Governance and Total Quality Management on the Effectiveness of Vocational School-based Entreprise

Arie Wibowo Khuriniawan, Illah Sailah, Pudji Muliono, M Syamsul Maarif, Bambang Indriyanto

than $\alpha(0.05)$, it is said that the hypothesis is accepted, and there is a significant influence of exogenous latent variables on endogenous latent variables. The comparison value is obtained from table $t$ with a significance level of $5 \%$, which is 1.96 . The statistical test values are shown in Table 3.

Table 3 Results of estimation of SEM models

\begin{tabular}{llllll}
\hline Hypothesis Relationship of Latent Variable & $\begin{array}{l}\text { Original } \\
\text { Sample }\end{array}$ & T Statistics & P Values & Keterangan \\
\hline $\mathrm{H}_{1}$ & $\mathrm{TQM} \rightarrow \mathrm{SG}$ & 0.896 & 25.478 & $0.000^{* *}$ & accepted \\
$\mathrm{H}_{2}$ & $\mathrm{SG} \rightarrow$ School Effectiveness & 0.158 & 2.144 & $0.033^{* *}$ & accepted \\
$\mathrm{H}_{3}$ & $\mathrm{TQM} \rightarrow$ School Effectiveness & 0.816 & 11.345 & $0.000^{* *}$ & accepted \\
$\mathrm{H}_{4}$ & $\mathrm{TQM} \rightarrow \mathrm{SG} \rightarrow$ School Effectiveness 0.141 & 2.035 & $0.042^{* *}$ & accepted \\
\hline
\end{tabular}

Note: $* *=$ significant at $\alpha=0.05$

\section{The Effect of TQM on $S G$}

The path coefficient value of TQM to SG is 0.896 , with a t-test of 25.478 and a p-value of 0.000 . This means that the TQM variable had a positive and significant effect on SG. The positive coefficient value explained that the better the application of TQM in the vocational school-based enterprise, the better the governance carried out by the school. This result is in line with Liantos \& Pamatmat (2016) stating that TQM practices, especially those relating to leadership that focuses on clients, continuous improvement, data-based decision making, professional learning, and focus on systems, have a relationship with leading schools and effect improvement in terms of staff development.

\section{The Effect of SG on School Effectiveness}

The path coefficient on SG towards school effectiveness is 0.158 , with a t-test of 2.144 and a p-value of 0.033 . This means that the SG latent variable had a positive and significant effect on the school effectiveness latent variable. The positive coefficient value explained that the better the application of SG in the vocational school-based enterprise, the better the effectiveness of the school. The results of this conclusion are in line with research conducted by Volansky \& Friedman (2003) and Bandur (2008), stating that schools that implement the SG component will significantly improve teaching and learning processes and provide significant improvements, both improving education and learning achievement and increased school effectiveness.

\section{The Effect of TQM on School Effectiveness}

The path coefficient on TQM on school effectiveness is 0.816 , with a t-test of 11.345 and a p-value of 0.000. This explained that the TQM latent variable had a positive and significant effect on the latent variable of school effectiveness. The positive coefficient value explains that the better the application of TQM in the vocational school-based enterprise, the better the effectiveness of the school. The results of this conclusion are in line with research conducted by Peat, Taylor, \& Franklin (2005); Hasan, Islam, Shams, \& Gupta (2018); Sadikoglu \& Olcay (2014); Venkatraman (2007); Wani \& Mehraj (2014) stating that educational institutions need to adopt the philosophy of TQM in order to create school effectiveness that is demonstrated through better performance.

\section{The Effect of TQM on School Effectiveness through SG}

The path coefficient on the latent variable TQM on school effectiveness through SG has a value of 0.141 with a t-test of 2.035 and a p-value of 0.042 . This means that the TQM latent variable had a positive and significant effect on the latent variable of school effectiveness through SG. The positive 
Proceeding on International Conference of Science Management Art Research Technology (IC-SMART),

Vol. 1 (1), 1-10

Analysis of the Effect of School Governance and Total Quality Management on the Effectiveness of Vocational School-based Entreprise

Arie Wibowo Khuriniawan, Illah Sailah, Pudji Muliono, M Syamsul Maarif, Bambang Indriyanto

coefficient value explains that the better the application of TQM and SG in SMK, the better the effectiveness of the school. The effect of latent TQM variables on latent variables of school effectiveness through the application of SG has never been studied statistically before, but according to Liantos \& Pamatmat (2016), TQM implementation, in general, has an influence on school leadership because TQM practices have a relationship with staff development and school leadership in carrying out its role in SG. On the other hand, Arar \& Nasra (2018) revealed that there is a positive relationship between SG and school effectiveness. According to him, with the existence of SG practices, the principal's decision-making authority, school decision-making, and the involvement of the school board can emerge so as to be able to create a better teaching and learning environment and student academic achievement that are indicators of effective schools (Bandur, 2012; Gamage \& Zajda, 2009). By combining the results of these studies, it was implied that TQM had a role in creating the application of SG, which could ultimately increase school effectiveness. The combined results of the study are in line with the results of this study, which concluded that the latent variable TQM significantly influences the latent variable of school effectiveness through SG.

\section{CONCLUSION AND FURTHER RESEARCH}

In order to increase the effectiveness of management in the vocational school-based enterprise to the maximum level, schools need to encourage governance and management through the implementation of School Governance (SG), as well as the implementation of integrated quality management (TQM), both separately and together. The results show that the modeling was valid, consistent, and good modeling. In addition, it is found that SG and TQM had a positive and significant effect on improving the effectiveness of the management of vocational school-based enterprises with R2 by $92.2 \%$.

Based on research that has been done, the advice used as material for further research is to analyze whether there are differences in strategies in increasing school effectiveness, both for schools with vocational school-based enterprise and for schools that have not and or will be going to be vocational school-based enterprise.

\section{REFERENCES}

[APO] Asian Productivity Organization. (2018). APO Productivity Databook 2018. Japan: Asian Productivity Organization.

[BPS] Badan Pusat Statistik. (2020). Laporan Bulanan Data Sosial Ekonomi (9th ed.; Subdirektorat Publikasi dan Kompilasi Statistik, Ed.). Jakarta: Badan Pusat Statistik.

[Kemenpppa] Kementerian Pemberdayaan Perempuan dan Perlindungan Anak. (2018). Profil Generasi Milenial Indonesia. Jakarta: KEMENPPPA.

Arar, K., \& Abu-Romi, A. (2016). School-based management: Arab education system in Israel. Journal of Educational Administration, 54, 191-208.

Arar, K., \& Nasra, M. A. (2018). Linking School-Based Management and School Effectiveness : The influence of self-based management, motivation and effectiveness in the Arab education system in Israel. Educational Management Administration \& Leadership., 48, 186-204.

Bandur, A. (2008). A study of the implementation of school-based management in flores primary schools in Indonesia. University of Newcastle.

Bandur, A. (2012). School-based management developments : challenges and impacts. Journal of Educational Administration., 50, 845-873.

Bergman, B., \& Klefsjö, B. (1994). Quality From Customer Needs to Customer Satisfaction. McGraw-Hill: London and Studentlitteratur Lund.

Caldwell, B. (2005). School-Based Management. Education Policy Series. UNESCO: International Academy of Education and International Institute for Educational Planning. 
Proceeding on International Conference of Science Management Art Research Technology (IC-SMART), Vol. 1 (1), 1-10

Analysis of the Effect of School Governance and Total Quality Management on the Effectiveness of Vocational School-based Entreprise

Arie Wibowo Khuriniawan, Illah Sailah, Pudji Muliono, M Syamsul Maarif, Bambang Indriyanto

Cardoso, S., Rosa, Maria, J., Videira, P., \& Amaral, A. (2018). Internal Quality Assurance: A New Culture or Added Bureaucracy? Assessment \& Evaluation in Higher Education., 44, 249-262.

Dotchin, J. A., \& Oakland, J. S. (2006). Theories and concepts in total quality management. Total Quality Management \& Business Excellence., 3, 133-146.

Gamage, D., \& Zajda, J. (2009). Decentralisation, School-Based Management, and Quality. Decentralisation, School-Based Management, and Quality. https://doi.org/10.1007/978-90-4812703-0

Grauwe, A. D. E. (2005). Improving the quality of education through school-based management: learning from international experiences. Review of Education., 51, 269-287.

Hasan, K., Islam, M., Shams, A., \& Gupta, H. (2018). Total Quality Management (TQM): Implementation in Primary Education System of Bangladesh. International Journal of Research in Industrial Engineering., 7, 370-380.

Hoy, C., Jardine, C., \& Wood, M. (2005). Improving Quality in Education. London: Falmer Press.

Hoyle, E. (1986). The Politics of School Management. London: Hodder and Stoughton.

Kanji, G., Malek, A., \& Tambi, B. (1999). Total quality management in UK higher education institutions. Total Quality Management., 10, 129-153.

Lezotte, L. (1992). Creating the Total Quality Effective School. Washington DC: Effective Schools Products Ltd.

Liantos, M., \& Pamatmat, F. (2016). Total quality management and school-based msnagement practices of school principlas: their implications to school leadership and improvement. International Research Journal of Social Sciences., 5, 1-7.

Nugroho, H. (2014). Conceptual model of it governance for higher education based on cobit 5 framework. Journal of Theoretical and Applied Information Technology., 60, 216-221.

Oakland, J. (2000). Total Quality Management (3rd ed.). Amsterdam: Text with Cases.

Peat, M., Taylor, C., \& Franklin, S. (2005). Re-Engineering of Undergraduate Science Curricula to Emphasize Development of Lifelong Learning Skills. Innovations in Education and Teaching International., 42, 135-146.

Quyen, D. (2014). Developing university governance indicators and their weighting system using a modified delphi method. ProcediaSocia and Behavioral Sciences., 141, 828-833.

Sabas, J., \& Mokaya, S. O. (2015). The Influence of Governance Systems on Students Performance in Public Secondary Schools in Karatu. International Journal of Science and Research., 5, 15951598.

Sadikoglu, E., \& Olcay, H. (2014). The Effects of Total Quality Management Practices on Performance and the Reasons of and the Barriers to TQM Practices in Turkey. Hindawi Publishing Corporation., 1-17.

Sallis, E. (2010). Manajemen Mutu Terpadu Pendidikan (Alih Bahasa: Ahmad Ali Riyadi). Yogyakarta: Ircisod.

Scheerens, J. (2000). Improving school effectiveness: Fundamentals of Educational Planning. Paris: UNESCO.

Scheerens, J. (2013). The use of theory in school effectiveness research revisited. School Effectiveness and School Improvement., 24, 1-38.

Summers, D. (2006). Quality (4th ed.). New Jersey: Pearson Prentice Hall.

Venkatraman, S. (2007). A Framework for Implementing TQM in Higher Education Programs. Quality Assurance in Education., 8, 103-131.

Volansky, A., \& Friedman, I. (2003). School-based Management: An International Perspective. London: Routledge.

Wani, I., \& Mehraj, H. (2014). Total Quality Management in Education:An Analysis. International Journal of Humanities \& Social Science Invention., 3, 71-78. 